\author{
Ulyana Balyk \\ PhD, Associate Professor of the Department of Marketing and Logistics, \\ National University "Lviv Polytechnic" (Lviv, Ukraine); \\ Mykhailo Kolisnyk, \\ PhD, Ukrainian Catholic University (Lviv, Ukraine);
}

\title{
MARKETING AUDIT OF INNOVATION ACTIVITY OF ENTERPRISES: THEORETICAL AND METHODICAL APPROACH
}

The essence, objectives and peculiarities of marketing audit of innovation activity of enterprises have been identified. A methodical approach to conduction of an audit at enterprises involved in the innovation activity was proposed, based on the Ukrainian legal framework concerning auditing activity and analysis of theoretical and applied studies on marketing audit. A system of indices for the evaluation of efficiency of innovation marketing was developed.

Keywords: audit, marketing, innovation activity, organizational structure, innovative potential, efficiency.

DOI: 10.21272/mmi.2017.3-09

Problem statement. Innovations are the basis for economic growth and competitiveness of enterprises. Present conditions under which Ukrainian enterprises conduct their innovation activity are determined by appearance of new needs in the society, which causes the scientific and technical progress to accelerate accordingly, forcing the shift to the forth industrial revolution and simultaneous transformation of the competitive environment. All this encourages managers to be as flexible to external challenges as possible and to reconsider the current marketing strategy in order to increase competitiveness of an enterprise at the market of innovations. As a result, the role of marketing audit is becoming more significant and the need to research its theoretical and applied aspects in the area of innovations is arising.

Analysis of the latest researches and publications. In recent years in Ukraine exists an increasing tendency towards researches concerning improvement of innovation activity. In particular, the team of authors under supervision of V. Heyets in the national report entitled "Innovative Ukraine 2020" has made a comprehensive study on key problems in the development of innovation activity of enterprises, regions and the country in general [8]. Theoretical, methodical and applied aspects concerning the interconnections between innovations, marketing and management have been thoroughly studied by the team of authors under supervision of S. Illiashenko. In particular, they elaborate such issues of marketing audit as: management of enterprise's innovation potential on the basis of marketing; monitoring of the integrated system for the management of innovative development [10, p. 151-162, 202-210].

The study of theoretical and applied aspects of marketing audit had been conducted much earlier abroad (back in the 1950s) than in Ukraine. As a result, it had its influence not only on forming of theoretical basis, but also on application of marketing audit. Thus, F. Kotler sees marketing audit as a full, systematic, independent and repeated within the same periods of time research of marketing environment, goals, strategies and activity of a company or its business unit [20]. A. Wilson has a similar vision - a method of an independent analysis and identification of marketing resources, which are underused [24]. M. Taghian and R. Shaw define marketing audit as a tool, which can aid with creation, technical support and management of market orientation strategy [22]. These authors have also studied the influence of marketing audit upon the change of market share of an enterprise. D. Brownlie tries to 
reveal the process essence and the methodology of marketing audit from the point of view of its practical application at enterprises of different types [19].

Among the latest works by Ukrainian researchers of marketing audit a special attention is to be paid to the ones by T. Butynets, who investigates not only the essence of "marketing audit", but also the coherence of its application in theory, practice and the national legal framework [3]. Instead, L. Balabanova and Yu. Logvina have developed a scientific and methodical approach to conduction of an audit of strategic management of marketing activity [2]. In the dissertation by K. Faizulaieva the theoretical and methodical findings are deepened, while the scientific and practical recommendations for organizing of a marketing audit at industrial enterprises are developed. In particular, the author views the marketing audit as a process of examination of enterprise's marketing activity in order to detect the drawbacks and possibilities for the quality improvement of marketing activity and to provide practical recommendations for overcoming these drawbacks and introducing measures for utilization of reserves $[15, p .7]$.

Issues unsolved. On the basis of analysis of the latest researches and publications it can be concluded that in the studies focused on peculiarities of enterprises' innovation activity development researchers do not pay enough attention to the issues of marketing audit, in particular, to the methodology of its conduction. Thus, the problem of applying marketing audit at enterprises involved in the innovation activity remains unresolved. Taking this into consideration, there is a need in further indepth study of the issue with regard to modern tendencies of marketing development.

The aim of the article is to determine the essence of marketing audit of innovation activity of enterprises, its tasks and subject, to present the methodical approach to conduction of marketing audit of innovation activity of industrial enterprises.

The main results of the research. According to the Law of Ukraine "On Innovation Activity", innovation activity is the one directed at utilization and commercialization of results of scientific studies and researches, and causes the market launch of new competitive products and services [7]. Therefore, the main task of innovation marketing in an enterprise is to search for the new areas and ways to utilize enterprise's potential, continuing in the development of new products, services and management technologies and marketing them in order to meet the needs and demands of consumers in a way more efficient than the competitors; making profit due to these activities and ensuring the conditions for longterm survival and development on the market [10, p. 269]. Thus, marketing specialists at an industrial enterprise involved for the innovation activity are responsible for production path of innovative products, their marketing and growth of demand for the new products.

According to the latest data of the World Intellectual Property Organization [23], Ukraine is the $56^{\text {th }}$ out of 141 countries in terms of innovations development. At the same time only $17 \%$ of industrial enterprises were conducting innovation activity in Ukraine in 2015 [12]. This is quite a low number. For example, the average share of such enterprises in EU is 52\% [21]. In general, in 201510.8 billion UAH worth of innovative products have been exported from Ukraine. It should be mentioned that every forth innovation-active enterprise in Ukraine has launched an innovative product on the market, two thirds of which have been exported. Yet, only $69.2 \%$ of enterprises conducting innovation activity managed to sell innovative products. Thus, despite possessing an innovative potential, industrial enterprises encounter a problem during sales of innovative products, one of key endogenous factors for this being the inefficient innovation marketing.

Marketing audit, which has been proving its effectiveness abroad for decades, is an efficient tool for the improvement of innovation marketing at Ukrainian enterprises. It should be conducted in the following cases: to enhance efficiency of marketing department performance and of innovation marketing in general; to optimize the innovation marketing costs; to check for relevance between the marketing strategy and aims of innovation activity development in an enterprise; to look for possibilities of utilization of innovative potential in an enterprise. Besides, marketing audit of innovation activity is conducted in case problems with marketing of innovative products are detected or volumes of their sales have decreased. In particular, low sales of 
innovative products can indicate either a wrong choice of indicators for monitoring of the working environment during the substantiation of a marketing strategy or a wrong choice of qualitative and quantitative parameters determining an innovative product. There is also a possibility that marketing specialists have not chosen suitable product marketing methods, which do not fully reveal all its advantages. In this context, low product sales can result from poor competence of supply or sales personnel. Another reason could be the insufficient technological capacity of an enterprise to satisfy the consumers' demands.

Marketing audit of innovation activity differs fundamentally from an ordinary audit, which according to the Law of Ukraine "On Auditing Activity" is the verification of accounting data and indicators in financial reports of an entity aimed to express an auditor's independent opinion on its fairness within all the significant aspects and compliance with requirements of legal framework of Ukraine, accounting guidelines (standards) or other rules (including internal standards of entities) in accordance with consumers' demands [6]. Taking into account the specificity of innovation marketing, it is not limited to examination of financial reports but also has to include analysis of a quite broad spectrum of data on internal and external environment of an enterprise.

The advantages of using a marketing audit of innovation activity are: an effective system of permanent control over the marketing of innovations and the innovation activity in general; estimation of the quality of marketing of innovations and its conformity to enterprise's development strategy; identification of undisclosed opportunities of innovative potential of an enterprise; timely detection of flaws and risks of innovation activity of an enterprise. Instead, the main drawbacks of the marketing audit of innovation activity are: increase in the costs of the management process; increase in the volumes of information flows associated with innovation activities.

Based on the analysis of different research approaches to the essence of marketing audit [1-3; 9-10; $15 ; 18-20 ; 22 ; 24]$ we suggest to define the marketing audit of innovation activity as the process of conduction of a complex verification of the efficiency in the marketing of innovations with regard to the aims of an enterprise, detection of unused reserves of innovative potential, development of proposals and recommendations for innovation marketing enhancement at an enterprise. Consequently, we outline the following key objectives of marketing audit of innovation activity:

- evaluating efficiency of an innovation marketing system and marketing potential of an enterprise;

- evaluating external and internal environment of an enterprise;

- checking the coherence between the marketing and innovation strategies of an enterprise and their compliance with modern requirements of economic management;

- estimating the competitiveness of an innovative product;

- evaluating innovative potential of an enterprise;

- verifying the efficiency of marketing activity in terms of utilization of enterprise's innovative potential;

- detecting weak points in current marketing activity of an enterprise;

- developing of proposals to enhance the innovation marketing.

Since the marketing audit fulfils quite a wide range of tasks, researchers view it at the same time as one of the stages in marketing activity planning, as the control tool and as an analytical management function $[9$, p. 9-10], which provides regulation of tactical plans and coordination of strategic and innovative development plans of an enterprise. Thus, we conclude that the best way to examine marketing audit of innovation activity is through the lens of a unifying function of management.

Marketing audit of innovation activity, same as a general marketing audit, can be conducted in different ways and by different agents: internal (self-audit, by an audit department of an enterprise, by a specially formed expert group, cross-sectional audit by upper-level departments or organizations) and external (by audit or consulting companies) [20].

The classic audit process consists of such main phases as planning, evaluation, checking the results reliability and reporting [6]. Various researchers base their methodical approaches to conduction of marketing audit on this algorithm. In particular, S. Koriagina and M. Koriagin single out six phases of marketing audit process: 1) planning; 2) examination; 3) analysis and processing of results; 4) producing recommendations; 5) preparation, approval and presentation of the report; 6 ) implementation and supervision of results [9, p. 30]. 
Instead, $\mathrm{O}$. Amelnytska suggests to focus solely on one product while conducting a marketing audit, and not on the set of products, and to carry it out in eight phases: 1) choosing a product; 2) defining the market; 3) market segmentation; 4) identification of key factors; 5) development of measures; 6 ) evaluation of measures; 7) selection and ranking of measures and 8) implementation [1, p. 51]. In our opinion, such approach is applicable in case when there is a small range of products produced by an enterprise; however, it does not give a complete picture of the effectiveness of marketing department of an enterprise or its influence on innovation activity of an enterprise in general.

K. Faizulaieva states that marketing audit at an enterprise should be conducted in the following order: organizational phase; research and analytic phase; a phase of marketing enhancing at an enterprise and implementation of changes [15]. However, this approach is based solely on the organizational aspect in utilization of marketing potential.

Therefore, taking the norms of the Ukrainian legal framework on auditing activity [6] and studies by marketing audit researchers $[1-3 ; 9-10 ; 15 ; 18 ; 20 ; 24]$ as the basis, the author suggest to conduct the marketing audit in five phases (figure 1).

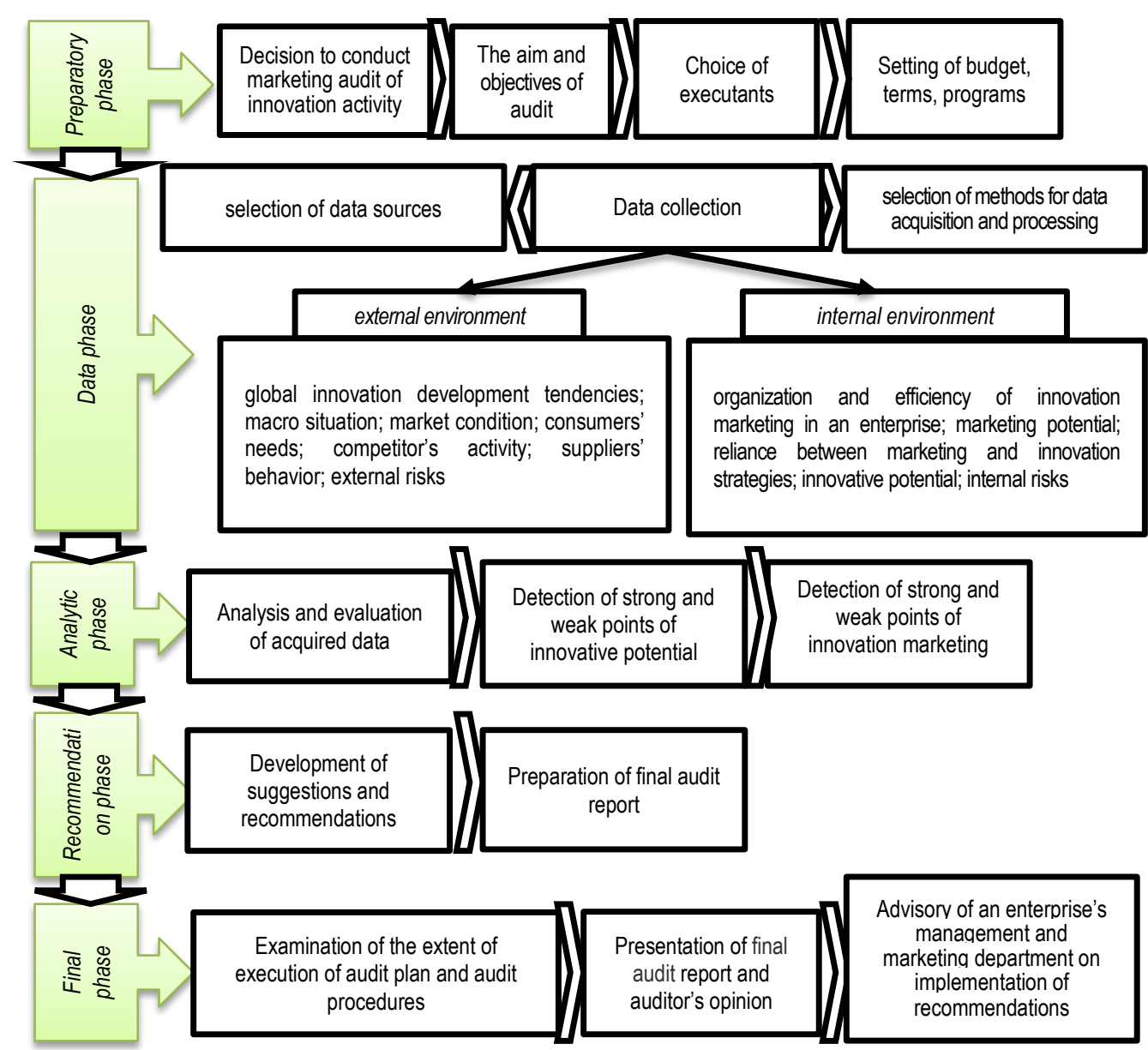

Figure 1 - Stages of marketing audit of innovation activity in an enterprise 
The first phase is a preparatory one, at which first and foremost a decision to conduct an audit is made. Also at this phase the aim and objectives of marketing audit of innovation activities are set, executants are appointed, terms of conducting are set, a plan and a program are developed and a budget is calculated.

The second and the third phases are data and analytic accordingly, which combined include the acquisition and processing of data concerning external and internal environment of an enterprise. In our opinion the marketing audit of innovation activity is meant to provide a qualitative evaluation not only on efficiency of organizing of innovation marketing in an enterprise, but also on external threats and possibilities to utilize an enterprise's innovative potential. With regard to the objectives of audit, data sources, methods of its collection and interpretation are defined.

The data on external environment is quite extensive as it contains information not only on social and economic situation in the country and on global innovation development tendencies, but also data on the sector's condition, the market, consumers' needs, competitors' activity, legal regulation of an enterprise's activity. Consequently, the information is taken from both official sources (State Statistics Service of Ukraine, official data of the Government of Ukraine, National Bank of Ukraine, international rating agencies, national and international institutions and organizations, etc.) and personal research (surveys, insider information, etc.).

External data needed for marketing audit of innovation activity can be divided into the following groups:

1) global innovation development tendencies (new and possible directions of innovation development, the place of Ukraine according to international innovation rankings, etc.);

2) macro situation (legal, economic, social, technical, ecological and other factors influencing development of innovation activity of an enterprise);

3) market condition (market size, existing niche markets, an enterprise's share in the market, search for new sales markets);

4) consumers' needs (satisfaction level of consumers' current need by existing innovative products, detection and foreseeing of new consumers' needs);

5) competitors (identifying competitors, strengths and weaknesses in their innovation marketing);

6) suppliers (evaluation of current suppliers' activity directed at optimization of marketing of innovative products).

The first phase is a preparatory one, at which first and foremost a decision to conduct an audit is made. Also at this phase the aim and objectives of marketing audit of innovation activities are set, executants are appointed, terms of conducting are set, a plan and a program are developed and a budget is calculated.

The second and the third phases are data and analytic accordingly, which combined include the acquisition and processing of data concerning external and internal environment of an enterprise. In our opinion the marketing audit of innovation activity is meant to provide a qualitative evaluation not only on efficiency of organizing of innovation marketing in an enterprise, but also on external threats and possibilities to utilize an enterprise's innovative potential. With regard to the objectives of audit, data sources, methods of its collection and interpretation are defined.

The data on external environment is quite extensive as it contains information not only on social and economic situation in the country and on global innovation development tendencies, but also data on the sector's condition, the market, consumers' needs, competitors' activity, legal regulation of an enterprise's activity. Consequently, the information is taken from both official sources (State Statistics Service of Ukraine, official data of the Government of Ukraine, National Bank of Ukraine, international rating agencies, national and international institutions and organizations, etc.) and personal research (surveys, insider information, etc.).

External data needed for marketing audit of innovation activity can be divided into the following groups:

1) global innovation development tendencies (new and possible directions of innovation development, the place of Ukraine according to international innovation rankings, etc.);

2) macro situation (legal, economic, social, technical, ecological and other factors influencing development of innovation activity of an enterprise);

3) market condition (market size, existing niche markets, an enterprise's share in the market, search for new sales markets); 
4) consumers' needs (satisfaction level of consumers' current need by existing innovative products, detection and foreseeing of new consumers' needs);

5) competitors (identifying competitors, strengths and weaknesses in their innovation marketing);

6) suppliers (evaluation of current suppliers' activity directed at optimization of marketing of innovative products).

Data on internal environment of an enterprise can primarily be found in financial reports and databases of different departments (marketing, innovation, economic, sales, production, research, etc.)

The main emphasis during the examination of internal data by an auditor is made on organization of innovation marketing in an enterprise, analysis of communication efficiency between all the departments of an entity and marketing department, staffing and defining an enterprise's marketing potential in general. Thus, the search of strengths and weaknesses in an enterprise's innovation marketing is conducted in terms of the organizational aspect.

The next step would be to determine the implementation efficiency of previously planned measures according to the existing marketing strategy for development of innovation activities. An auditor examines existing marketing and innovation strategies of an enterprise, notes the achieved and unachieved goals, major contradictions and compliance with modern requirements of economic management.

In our opinion based on different researchers' approaches [4; $5 ; 13 ; 17]$, effectiveness of innovation marketing can be determined by six indicators, which reflect the results of marketing activity through the output of innovation activities of an enterprise (table 1).

\section{Table 1 - Indicators of innovation marketing effectiveness}

\begin{tabular}{|c|l|l|}
\hline No. & \multicolumn{1}{|c|}{ Indicator } & \multicolumn{1}{|c|}{ Recommended value } \\
\hline 1 & $\begin{array}{l}\text { Return on marketing expenses for innovation activity = Profit from } \\
\text { innovation activity * 100\% / marketing expenses for innovation activity }\end{array}$ & Higher than an average sectoral indicator \\
\hline 2 & $\begin{array}{l}\text { Return on innovation activity = Sales volume of innovative products * } \\
100 \% \text { / Expenses on innovative products' development, production } \\
\text { and sales }\end{array}$ & $\begin{array}{l}\text { Higher than an average amount of bank credit } \\
\text { inte }\end{array}$ \\
\hline 3 & Volume of sales of innovative products & Increase \\
\hline 4 & $\begin{array}{l}\text { Innovative products sales' share in a general volume of industrial| Increase } \\
\text { products sales }\end{array}$ & Increase or a set value in a marketing strategy \\
\hline 5 & Enterprise's share in the market & Increase \\
\hline 6 & Number of clients, agreements signed &
\end{tabular}

Evaluation of an enterprise's innovative potential plays a key role for the analysis of internal environment. It deals not only with determining of its current condition and efficiency, but also with detecting unused reserves to increase innovation activity indicators and, consequently, an enterprise's profit. Innovative potential is primarily an ability to create a new value due to targeted combination of tangible and intangible assets, which guarantees innovational development of an enterprise [16, p. 17].

Currently a variety of methods exist for evaluation of enterprises' innovative potential $[11 ; 13 ; 16]$, since researchers are not unanimous on elements of such potential. At the same time majority of authors agree that human, technical and technological, research and development, management and production elements are fundamental for innovative potential. Additionally, G. Goldstein, R. Fathudinov and I. Fesenko also add an element of marketing [11, p. 24].

The author is inclined to think that through the lens of marketing audit it is relevant to examine the organizational and management, marketing, human resources, research, technical and technological, production and financial elements of innovative potential. Additionally, evaluation of innovative potential should allow to determine new possibilities to implement research results in an enterprise (by means of human resources, technologies, management decisions, investors, etc.), new technologies that could be commercialized and other.

An auditor should pay a special attention to: examining of new marketing technologies in an 
enterprise (with singling out the main ones); their implementation by the enterprise and competitors; sources of these technologies (own, acquired); defining an enterprise's place at the technology market; efficiency of existing correlation between own and acquired technologies; level of readiness of new innovative products to enter the market.

Within the analysis and evaluation of external and internal environment an important role goes to identifying risk levels, since being caused by exogenous and endogenous factors of impact on an enterprise, risks can lead to results different from the expected, both in innovation activities in general and in marketing measures applied to particular activities [14, p. 21]. The main external risks are political, legislative, economic, social, technical and technological, which in fact determine the conditions of an enterprise's activities. Besides, influence of global innovation tendencies, competitors' activity, consumers' demands, suppliers' activity and other are taken into consideration. While internal risks, in our opinion, are reflected within the elements of innovative potential. This, in its turn, should aid in singling out the weak points. Among the main marketing risks are the low competitiveness of innovative products, a wrong choice within the price strategy, noncompliance of technical and economic parameters of innovative products with consumers' demands, and other. At the same time, administrative risk is the greatest, since the ability not only to prevent the existing threats, but to transform them into possibilities, depends primarily on the management of an enterprise.

In general, at the analytic stage of audit it is necessary to single out the weaknesses of innovation marketing and the issues, which an auditor has not managed to solve.

It is necessary to emphasize that at each phase of marketing audit specification of an audit program is carried out depending on the research results obtained.

The forth (recommendation) phase of marketing audit of innovation activity is based on assessment of different elements of external and internal enterprise's environments, analysing relevance between marketing measures and strategic vision of innovation activity development and, consequently, detecting weak and strong points. It allows developing a set of suggestions and recommendations for further innovation marketing strategy. Then, the results of conducted audit are issued in the form of audit report and audit opinion.

The final audit phase aims to check fulfilment of all existing audit tasks, completeness of an implementation plan and performance of audit procedures. An audit report and audit opinion are presented to upper management of an enterprise (client), consultations with an enterprise's staff concerning the enhancement of marketing innovations and implementation of audit suggestions and recommendations are carried out.

Conclusions. On the basis of the conducted research it can be concluded that the relevance of marketing audit constantly increases. It has managed to successfully establish itself in practice of developed countries; however, it has not become popular enough with the domestic enterprises yet. Considering a significant innovative potential of Ukraine, enhancement of innovation marketing at domestic enterprises by conducting a relevant audit is an essential precondition for its successful development. Accordingly, a methodical approach has been developed to conduct a marketing audit of innovation activity at industrial enterprises, which in contrast to the existing ones includes a comprehensive evaluation of innovation marketing in an enterprise though the lens of an organizational aspect, efficiency, possibilities and risks of innovative potential utilization. It gives managers a possibility to enhance innovation marketing according with the conditions of an enterprise's external environment and internal abilities.

Further researches on the subject should be directed at studying of the foreign and domestic practice of management of innovation activities at industrial enterprises. In particular, the main emphasis should be put on peculiarities of utilization of marketing innovations and search for the ways to enhance their implementation in Ukraine.

1. Амельницька О.В. Формування системи маркетингового аудиту на промислових підприємствах / О.В. Амельницька // Вісник Хмельницького національного університету. - 2010. - № 6. - Т. 4. - С. 50-53.

2. Балабанова Л.Б. Стратегічне управління маркетинговою діяльністю підприємств: монографія / Л.В. Балабанова, Ю.М. Логвіна. - Донецьк : ДонНУЕТ, 2012. - 235 с. 
3. Бутинець Т.А. Маркетинговий аудит: відмінності у трактуванні // Т.А. Бутинець / Проблеми теорії та методології бухгалтерського обліку, контролю і аналізу. Сер.: Бухгалтерський облік, контроль і аналіз: міжнар. зб. наук. пр. / Житомир. держ. технол. ун-т. - Житомир: ЖДТУ, 2015. - Вип. 3 (33). - С. 3-16.

4. Глухова С.В. Сучасні підходи до оцінки ефективності інноваційної діяльності підприємства / С.В. Глухова // Вісник НТУ «ХПІ». Серія: Технічний прогрес і ефективність виробництва. - Х.: НТУ «ХПІ». - 2013. - № 20 (993). - С. 135-140.

5. Євтушенко С.В. Шляхи вдосконалення оцінки ефективності інновацій на підприємстві / С.В. Євтушенко // Вчені записки Університету «Крок». - 2008. - №18. - С. 56-65.

6. Закон України «Про аудиторську діяльність» від 22 квітня 1993 року [Електронний ресурс]. - Режим доступу: http://zakon5.rada.gov.ua/laws/show/3125-12.

7. Закон України «Про інноваційну діяльність» від 4 липня 2002 року [Електронний ресурс]. - Режим доступу: http://zakon3.rada.gov.ual/laws/show/40-15.

8. Інноваційна Україна 2020: національна доповідь / за заг. ред. В.М. Гейця та ін. ; НАН України. - К., 2015. - 336 с

9. Корягіна С. В. Маркетинговий аудит / С.В. Корягіна, М.В. Корягін. - К.: «Центр учбової літератури», 2014 - 320 с.

10. Маркетинг. Менеджмент. Інновації: монографія / за ред. д.е.н., професора С. М. Ілляшенка. - Суми : ТОВ «Друкарський дім «Папірус», 2010. - 621 с.

11. Механізм управління потенціалом інноваційного розвитку промислових підприємств: монографія / за ред. к.е.н., доцента Ю.С. Шипуліної. - Суми: ТОВ «ДД «Папірус», 2012. - 458 с.

12. Наукова та інноваційна діяльність [Електронний ресурс]. - Державна служба статистики України. - Режим доступу: http://www.ukrstat.gov.ual.

13. Панас Я. В. Концептуальний підхід до оцінювання здатності реалізовувати інноваційний потенціал підприємства в контролінгу / Я.В. Панас // Інноваційна економіка. - 2014. - № 6. - С. 129-133.

14. Ткач С.М. Управління ризиками інвестиційної діяльності в регіоні: теоретичні основи та прикладні аспекти: монографія / С.М. Ткач. - Львів: ДУ «Інститут регіональних досліджень імені М. І. Долішнього НАН України», 2015. - 234 с.

15. Файзулаєва, К.А. Організація маркетингового аудиту на промисловому підприємстві: автореф. дис. ... канд. екон. наук: 08.00 .04 / К.А. Файзулаєва; Харк. нац. екон. ун-т. - Х., 2012. - 20 с.

16. Чухрай Н.І. Формування інноваційного потенціалу підприємства: маркетингове і логістичне забезпечення: монографія / Н.І. Чухрай. - Львів: Вид-во НУ «Львівська політехніка», 2002. - 315 с.

17. Шерстобитова Т.И. Маркетинг инноваций: учеб. пособие / Т.И. Шерстобитова. - Пенза: Издательство ПГУ, 2009. - 126 с.

18. Шоу Р. Прибыльный маркетинг: окупается ли ваш маркетинг? / Р. Шоу, Д. Меррик. - К. : Companion Group, 2007. - 496 c.

19. Brownlie D.T. The Marketing Audit: A Metrology and Explanation / D.T. Brownlie // Marketing Intelligence \& Planning. 1993. - № 11 (1). - P. 4-12.

20. Kotler Ph. The Marketing Audit Comes of Age / Philip Kotler, Gregor T. William, Rodgers H. III William. [Електронний ресурс]. - Режим доступу: http://sloanreview.mit.edu/article/the-marketing-audit-comes-of-age/.

21. Science, technology and innovation in Europe 2013 edition // Eurostat Pocketbooks: Luxembourg: Publications Office of the European Union, 2013. - $148 \mathrm{p}$

22. Taghian Mehdi \& Shaw Robin N. The Marketing Audit and Organizational Performance [Електронний ресурс] / Mehdi Taghian, Robin N Shaw II The Journal of Marketing Theory and Practice. - Режим доступу: https://www.researchgate.net/publication/247887303_The_Marketing_Audit_and_Organizational_Performance_An_Empirical_Profiling.

23. The Global Innovation Index 2016 [Електронний ресурс]. - Режим доступу: http://www.wipo.int/edocs/pubdocs/en/wipo_pub_gii_2016.pdf

24. Wilson A. The Marketing Audit Handbook: Tools, Techniques and Checklists to Exploit Your Marketing Techniques / A. Wilson. - Kogan Page. $-2002 .-285$ p.

1. Amelnytska, O.V. (2010). Formuvannia systemy marketynhovoho audytu na promyslovykh pidpryiemstvakh [Formation of system of marketing audit in industrial enterprises]. Visnyk Khmelnytskoho natsionalnoho universytetu - Herald of Khmelnytsky National University, 6(4), 50-53 [in Ukrainian].

2. Balabanova, L.B. \& Lohvina, Iu.M. (2012). Stratehichne upravlinnia marketynhovoiu diialnistiu pidpryiemstv: monohrafiia [Strategic management of marketing activity of enterprises]. Donetsk: DonNUET [in Ukrainian].

3. Butynets, T.A. (2015). Marketynhovyi audyt: vidminnosti u traktuvanni [Marketing audit: differences in the interpretation]. Problemy teorii ta metodolohii bukhhalterskoho obliku, kontroliu i analizu - Problems of theory and methodology of accounting, control and analysi,. 3(33), 3-16). Zhytomyr: Zhytomyr State Technological University [in Ukrainian].

4. Hlukhova, S.V. (2013). Suchasni pidkhody do otsinky efektyvnosti innovatsiinoi diialnosti pidpryiemstva[Current approaches to assessing the effectiveness of innovation enterprise]. Visnyk NTU «KhPl» - Herald NTU «KhPl», 20(993), 135-140. [in Ukrainian].

5. levtushenko, S.V. (2008). Shliakhy vdoskonalennia otsinky efektyvnosti innovatsii na pidpryiemstvi [Ways of improving the efficiency evaluation of innovation in the enterprise]. Vcheni zapysky Universytetu "Krok» - Scientific notes University «Step», 18, 56-65 [in Ukrainian].

6. Supreme Council of Ukraine (1993). Pro audytorsku diialnist [On auditing]: Law of Ukraine, adopted on 1993, April 22 3125-XII. Vidomosti Verkhovnoyi Rady Ukrayiny - The Official Bulletin of the Verkhovna Rada of Ukraine, 14 [in Ukrainian].

7. Supreme Council of Ukraine (2002). Pro innovatsiynu diyal'nist' [On the Innovation Activities]: Law of Ukraine, adopted on 2002, July 4, 40-IV. Vidomosti Verkhovnoyi Rady Ukrayiny - The Official Bulletin of the Verkhovna Rada of Ukraine, 36 [in Ukrainian].

8. Heiets, V.M. (Ed.) (2015). Innovatsiina Ukraina 2020 [Innovative Ukraine 2020] (National Report). Kyiv: the NAS of Ukraine. [in Ukrainian]. 
9. Koriahina, S.V. \& Koriahin, M.V. (2014). Marketynhovyi audyt [Marketing audit]. [Manual]. Kyiv.: «Center of educational literature», 320 [in Ukrainian].

10. Illiashenko, S.M. (Ed.) (2010). Marketynh. Menedzhment. Innovatsii [Marketing. Management. Innovation]. Sumy: LLC «Printing House "Papyrus"» [in Ukrainian].

11. Shypulina, lu.S. (Ed.) (2012). Mekhanizm upravlinnia potentsialom innovatsiinoho rozvytku promyslovykh pidpryiemstv [Mechanism of management of innovative potential of industrial enterprises]. Sumy: LLC «Printing House "Papyrus"». [in Ukrainian].

12. State Statistics Service of Ukraine. (2016). Naukova ta innovatsiina diialnist [Research and Innovation]. Website of State Statistics Service of Ukraine. Retrieved from http://www.ukrstat.gov.ual_[in Ukrainian].

13. Panas, la.V. (2014). Kontseptualnyi pidkhid do otsiniuvannia zdatnosti realizovuvaty innovatsiinyi potentsial pidpryiemstva v kontrolinhu [Conceptual approach to the assessment of the ability to realize the innovative potential of enterprises in controlling]. Innovatsiina ekonomika - Innovative Economy, 6, 129-133. [in Ukrainian].

14. Tkach, S.M. (2015). Upravlinnia ryzykamy investytsiinoi diialnosti v rehioni: teoretychni osnovy ta prykladni aspekty [Risk management of investment activity in the region: theoretical basis and applied aspects]. Lviv : SI «M. I. Dolishnyi Institute of Regional Research of the NAS of Ukraine» [in Ukrainian].

15. Faizulaieva, K.A. (2012). Orhanizatsiia marketynhovoho audytu na promyslovomu pidpryiemstvi [Organization of marketing audit in industrial enterprise]. (PhD in Econ. Thesis, Kharkiv National University of Economics, Kharkiv, Ukraine) [in Ukrainian].

16. Chukhrai, N.I. (2002). Formuvannia innovatsiinoho potentsialu pidpryiemstva: marketynhove i lohistychne zabezpechennia: monohrafiia [Formation of innovative potential of enterprise, marketing and logistics software]. Lviv: Publication $\mathrm{NU}$ «Lvivska politekhnika» [in Ukrainian].

17. Shestobitova, T.I. (2009). Marketynh innovatsii [Marketing Innovation]. [Manual]. Penza, Publication PGU, 126 p. [in Russian].

18. Shou, R., \& Merrik, D. (2007). Pribyilhyiy marketing: okupaetsya li vash marketing? [Profitable Marketing: Does your marketing pays off?]. Kyiv: Companion Group [in Russian].

19. Brownlie, D.T. (1993). The Marketing Audit: A Metrology and Explanation. Marketing Intelligence \& Planning, 11 (1), 4-12.

20. Kotler, Philip, William, T. Gregor, \& William, H. Rodgers III. (1989). The Marketing Audit Comes of Age. Website of Magazine. Retrieved from http://sloanreview.mit.edu/article/the-marketing-audit-comes-of-age/.

21. Science, technology and innovation in Europe. (2013). Eurostat Pocketbooks: Luxembourg: Publications Office of the European Union, 2013. - $148 \mathrm{p}$.

22. Taghian, Mehdi, \& Shaw, Robin N. (2008). The Marketing Audit and Organizational Performance: An Empirical Profiling. The Journal of Marketing Theory and Practice. Retrieved from: https://www.researchgate.net/publication/247887303_The_Marketing_Audit_and_Organizational_Performance_An_Empirical_Profiling.

23. The Global Innovation Index 2016 (2016). Website of World Intellectual Prpperty Organization. Retrieved from: http://www.wipo.int/edocs/pubdocs/en/wipo_pub_gii_2016.pdf.

24. Wilson, Aubrey (2002). The Marketing Audit Handbook: Tools, Techniques and Checklists to Exploit Your Marketing Techniques. Kogan Page.

У.О. Балик, к.е.н., доцент кафредри маркетингу та логістики, Національний університет «Львівська політехніка» (м. Львів, Україна);

М.В. Колісник, к.е.н., Український католицький університет (м. Львів, Україна)

Маркетинговий аудит інноваційної діяльності підприємств

Визначено суть, завдання та особливості маркетингового аудиту інноваційної діяльності підприємств. Базуючись на нормах вітчизняного законодавства про аудиторську діяльність та аналізі теоретико-прикладних досліджень маркетингового аудиту запропоновано методичний підхід до проведення маркетингового аудиту на підприємствах, які здійснюють інноваційну діяльність. Сфрормовано систему показників оцінювання ефективності маркетингу інновацій.

Ключові слова: аудит, маркетинг, інноваційна діяльність, організаційна структура, інноваційний потенціал, ефективність.

У.О.Балык, к.э.н., доцент кафредры маркетинга и логистики, Национальный университет «Львовская политехника» (2. Львов, Украина);

М.В. Колиснык, к.э.н., Украинский католический университет (е. Львов, Украина)

Маркетинговый аудит инновационной деятельности предприятий

Oпределена суть, задачи и особенности маркетингового аудита инновационной деятельности предприятий. Основываясь на нормах отечественного законодательства об аудиторской деятельности и анализе теоретикоприкладных исследований маркетингового аудита предложен методический подход к проведению маркетингового аудита на предприятиях, осуществляющих инновационную деятельность. Сфоормирована система показателей оценки эфффективности маркетинга инноваций.

Ключевые слова: аудит, маркетинг, инновационная деятельность, организационная структура, инновационный потенциал, эффрективность.

Отримано 18.03.2017 p. 